\title{
NILAI-NILAI PEMBANGUNAN ISLAM DALAM MASYARAKAT GAYO
}

\author{
Sukiman \\ Fakutas Ushuluddin IAIN Sumatera Utara \\ Jl. Willem Iskandar Pasar V Medan Estate, Medan, 20371 \\ e-mail: winsukiman@yahoo.com
}

\begin{abstract}
Abstrak: Sistem budaya masyarakat Gayo bernilai spiritual dan berorientasi akhlâq al-karîmah. Nilai-nilai budaya ini membentuk pergaulan hidup bersama berlandaskan syariat Islam. Tulisan ini bertujuan untuk menelaah dan mengangkat kembali nilai budaya Gayo yang dipandang relevan dengan ajaran Islam. Penulis menemukan bahwa nilai-nilai budaya Gayo; genap mupakat "syuro" (musyawarah), amanat (amanah), Tertib, Alang tulung beret bantu (saling-tolong menolong", Gemasih (kasih sayang), setie (setia), bersikemelen (berkompetisi) memiliki nilai-nilai spiritual bagi masyarakat Gayo. Sistem-sitem nilai tersebut menurut analisis penulis sejalan dengan ajaran Islam. Sinergisitas antara Islam dan nilai-nilai budaya Gayo pada akhirnya diharapkan mampu mewujudkan pembangunan al-insân al-kâmil dalam masyarakat Gayo. Hal ini tentunya dapat terwujud jika ada upaya nyata untuk mengimplementasikan nilai-nilai budaya tersebut pada tataran praktis.
\end{abstract}

Abstract: The Values of Islamic Development in Gayo Society. The system of Indonesian Gayo culture has spiritual dimension of value and virtuous character (akhlâq al-karîmah) orientation. Such cultural values form the relationship of living together based on the principles of Islamic shariah. This paper is aimed at analyzing and reconstructing Gayo cultural values perceived to be relevant with Islamic teaching. The author finds that the values of Gayo culture that includes mukemel (low hearted and honor), setie (faithful), semayang/gemasih (affection), mandate, genap mupakat (consolidation), alang tulung beret berbantu (helpful), bersikemelen (competitive) have spiritual values for Gayo society. Such value systems according to the author run parallel with the teachings of Islam. The synergy of Islam and the cultural values of Islam is finally hoped to be capable of producing perfect man or al-insân al-kâmil within Gayo society. And for this to be realized, there should be a more serious attempt to implement such cultural values at the practical level.

Kata Kunci: Nilai budaya, pembangunan, Gayo, Islam 


\section{Pendahuluan}

Masyarakat Gayo merupakan bagian integral dari bangsa Indonesia. Mereka memiliki karakter dan nilai-nilai adat dan budaya yang spesifik sebagaimana masyarakat Indonesia pada umumnya. Nilai-nilai adat istiadat dan budaya Gayo, mereka jadikan sebagai hukum adat $^{1}$ dalam kehidupan sehari-hari. C. Snouck Hurgronje, mengatakan bahwa, nilai-nilai tradisi masyarakat Gayo yang diungkapkan dalam berbagai pepatah adatnya, jika dilihat sepintas lalu, kadang-kadang mengandung pengertian yang mirip teka-teki. Akan tetapi, bagaimanapun juga kata-kata adat itu merupakan pegangan hukum adat, ${ }^{2}$ yang harus tetap hidup dan berkembang dalam sendi-sendi kehidupan masyarakat Gayo.

Sistem budaya masyarakat Gayo pada dasarnya bermuatan pengetahuan, keyakinan, nilai, agama, norma, aturan, dan hukum yang menjadi acuan bagi tingkah laku dalam kehidupan masyarakat. ${ }^{3}$ Karena itu, hukum adat Gayo adalah aturan atau perbuatan yang bersendikan Syariat Islam dituruti, dimuliakan, ditaati dan dilaksanakan secara konsisten (îstîqâmâh) dan menyeluruh (kâffâh) dalam upaya membangun masyarakat Gayo. Pembangunan pada hakikatnya adalah bagaimana upaya membuat penduduk suatu negeri (terutama kaum lemah dan kaum miskin) tidak hanya lebih produktif, tetapi juga secara sosial lebih efektif dan lebih sadar diri. ${ }^{4}$

Dalam perspektif Islam, pembangunan adalah masalah yang aktual sepanjang sejarah manusia. Manusia terus membangun untuk mencapai tarap kehidupan yang lebih baik dan sempurna. Setiap bangsa, termasuk masyarakat suku Gayo Indonesia terus berlomba untuk mengembangkan kreasi mereka di bidang pembangunan dan kebudayaan, selaras dengan fitrahnya yang hendak maju dan berkembang. Dalam al-Qur'an, Allah SWT., telah memberikan tuntunan terhadap pembangunan. Allah dan rasul-Nya telah menyuruh umat manusia bekerja keras atau beramal untuk membuat produk kebudayaan baru, membangun dalam segala bidang kehidupan manusia, seperti; ekonomi, sosial, budaya, politik, dan teknik, sekaligus berbarengan dengan pembangunan di bidang mental, moral dan spiritual. ${ }^{5}$

${ }^{1}$ Bahwa hukum adat merupakan nilai-nilai, norma sosial budaya yang hidup dan berkembang dalam masyarakat Gayo Aceh Tengah, karena perlu dikembangkan dalam tatanan sosial kehidupan masyarakat. Lihat, Qanun Kabupaten Aceh Tengah Nomor: 09 Tahun 2002 Tentang Hukum Adat (Takengon: Himpunan Qanun Kabupaten Aceh Tengah, 2002), h.138.

${ }^{2}$ C. Snouck Hurgronje, "Het Gajoland en Zijne Beworners", (terj.) Hatta Aman Asnah, Gayo, Masyarakat dan Kebudayaan Awala Abad 20 (Jakarta: Balai Pustaka, 1996), h. 70-71.

${ }^{3}$ M.J. Melalatoa, "Budaya Malu: Sistem Budaya Gayo", dalam Sistem Budaya Indonesia (Jakarta: Kerjasama Fak. Sosial dan Ilmu Politik UI dengan PT Pelajar, 1997), h. 2002.

${ }^{4}$ Keterangan di atas, dapat merujuk kepada tulisan Soedjatmoko, Pembangunan dan Kebebasan (Jakarta: LP3ES, 1984), h. 108.

5Istilah "Spiritual" adalah sebuah istilah yang berkaitan dengan filosofis dan religius. Secara filosofis, kadang istilah ini digunakan sebagai sinonim Idealisme. Dalam agama, adakalanya istilah ini mengacu kepeda penjelmaan Roh. Lihat, Lorens Bagus, Kamus Filsafat (Jakarta: Gramedia Pustaka Utama), h. 1035. Menurut Seyyed Hossein Nasr, bahwa istilah "Spiritual' bahwa siapa 
Secara kronologis, ada dua pola pembangunan yang diajarkan Islam, yaitu pola hidup bagi kepentingan dunia dan pola hidup untuk kepentingan akhirat. Dengan pola yang dibentangkan Islam tersebut menunjukkan bahwa setiap umat Islam hendaknya mempunyai perencanaan jauh ke depan, melewati jarak kehidupan manusia di dunia ini. Ia memikirkan kepentingan dunianya yang semu dan pendek ini secara realistis, karena betapapun keadaannya ia hidup di dunia ini. Di samping itu, ia mesti memperhitungkan hidupnya di akhirat atau alam ghâîb, yakni dunia baru dan kekal abadi. Bukankah manusia sebelum lahir ke dunia ini berada di alam ghâîb. Dari alam ghaib ke alam yang nyata dan kemudian akan kembali kepada alam gaib pula. Dengan demikian, tepatlah apa yang di firmankan Allah SWT., dalam al-Qur'an:

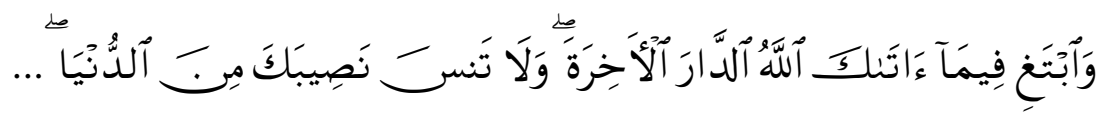

Dan carilah pada apa yang telah dianugerahkan Allah kepadamu (kebahagiaan) negeri akhirat, dan janganlah kamu melupakan bahagianmu dari (kenikmatan) duniawi. (Q.S. Al-Qashash/ 28: 77). ${ }^{6}$

Berbarengan dengan dua pola hidup itu, maka pembangunan spiritual, moral dan material harus seimbang. Pembangunan spiritual amat penting, malahan merupakan faktor mutlak dalam menyertai pembangunan material. ${ }^{7}$ Pembangunan spiritual meliputi pembinaan akidah, syariah dan akhlak. Untuk mewujudkan pembangunan spiritual dan moral dalam pembangunan masyarakat Gayo, maka sangat diperlukan penanaman nilainilai adat dan budaya yang relevan dengan hukum Islam dalam berbagai sendi kehidupan masyarakat Gayo. Karena adat dan hukum (edet urum ukum) tidak dapat dipisahkan atau sangat berpadu dalam pembangunan masyarakat Gayo. ${ }^{8}$

Nilai-nilai penting dalam adat dan budaya masyarakat Gayo dikenal prinsif bahwa

saja yang memandang Tuhan atau Ruh Suci sebagai norma yang penting dan menentukan atau prinsip hidupnya bisa disebut "spiritual". Lebih rinci baca, Seyyed Hossein Nasr, (terj.) Rahmani Astuti, Ensiklopedi Tematis Spiritualisme Islam (Bandung: Mizan Media Utama, 2002), h. 13.

${ }^{6}$ Departemen Agama RI, Al-Qur'an dan Terjemahnya (Jakarta: Yayasan Penyelenggara Penerjemah Al-Qur.an, 1984), h. 623.

${ }^{7}$ Keterangan di atas dapat merujuk kepada tulisan Misri A. Muchsin, bahwa pada hakikatnya pembangunan Indonesia-Aceh yang lagi berupaya penerapan syariat Islam. Karenanya yang ideal adalah mencakup fisik-material dan mental-spiritual, sebagaimana unsur diri manusia itu sendiri. Antara keduanya hendaknya seimbang, sehingga tidak berat sebelah. Ketika hanya mementingkan dan mengutamakan pembangunan fisik-jasadiyah, maka pembangunan mentalruhaniah akan terabaikan dan kondisi semacam itu akan membentuk manusia-manusia yang materialis, "pincang", dan "sekuler". Misri A. Muchsin, Potret Aceh Dalam Bingkai Sejarah (Banda Aceh: Ar-Raniry Press, Dicetak Oleh Satker BRR Penguatan Kelembagaan Kominfo NAD-NIAS, 2007), h. 184.

${ }^{8}$ Mahmud Ibrahim, "Peranan Islam Melalui Adat Gayo Dalam Pembangunan Masyarakat Gayo", dalam Makalah Seminar Ilmu Pengetahuan Dan Kebudayaan 20 - 24 Januari 1986 (Takengon: Diselenggarakan oleh MUI Provinsi Aceh dan MUI Aceh Tengah, 1986), h. 8. 
"Edet kuet muperala agama, rengang edet benasa nama, edet munukum bersifet ujud, ukum munukum berseifet kalam". (Maksudnya adat berjalan dituntun oleh hukum agama. Adat tidak kuat binasa nama. Adat menghukum bersifat wujud. Hukum agama itu adalah pasti). "Edet mungenal, ukum mubeza". (Adat mencari mana yang benar dan mana yang salah. Hukum membedakan mana yang benar dan mana yang salah). ${ }^{9}$ Jadi, Adat Gayo berfungsi untuk melaksanakan hukum berdasarkan kenyataan. Sedangkan hukum berdasarkan Firman Allah Swt., dan Rasululul-Nya dalam Alquran dan hadis.

Hubungan hukum adat dengan hukum agama sebagaimana dijelaskan oleh Tengku H. Abdullah Husni bahwa, hukum adat dan adat-istiadat menghukum bersifat wujud, artinya kata adat itu selaras dengan ketentuan hukum. Hukum menghukum bersifat kalam, artinya selaras dengan hâblûmînâllâh. Filsafat hukum ialah adat bersendikan syârâ', syârâ' bersendikan kepada adat. Maksudnya adalah adat-istiadat itu tidaklah akan kuat dan kokoh kalau sekiranya tidaklah bersumber kepada syârâ'. Hukum syârâ’ tidaklah akan terwujud dan terealisasi serta menjadi kenyataan dalam kehidupan dan pembangunan masyarakat kalau tidak dijadikan hukum adat sebagai pendukungnya. ${ }^{10}$ Dengan demikian, masyarakat Gayo harus berpegang kepada Hukum Islam dan adat Gayo. Dalam ungkapan masyarakat Gayo dikenal "Ukum urum edet, lagu zet urum sifet". Artinya hukum dengan adat seperti zat dengan sifat yang sukar dipisahkan. ${ }^{11}$ Karena itu, nilai-nilai pembangunan masyarakat Gayo tidak terlepas dari ketentuan hukum Islam dan adat-istidat/budaya masyarakat Gayo, seperti; Genap mupakat" syuro" (musyawarah), amanat (amanah), tertib, alang tulung beret bantu (saling-tolong menolong", gemasih (kasih sayang), setie (setia), bersikekemelen (berkompetisi), dan mutentu (berdayaguna).

Untuk mengetahui lebih mendalam tentang nilai-nilai pembangunan masyarakat Gayo di atas, perlu kajian lebih serius, sistematik dan radikal. Karena itu, kajian ini sangat menarik, bahkan sangat signifikan. Manfaatnya antara adalah sebagai kontribusi pemikiran kepada pemerintah daerah, tokoh adat, tokoh agama, pakar dan cendekiawan Muslim dalam membuat kebijakan untuk menata pembangunan masyarakat Gayo yang damai, adil, bijak, dan sejahtera.

Kerangka teori yang dibangun dalam kajian ini adalah berdasarkan teori yang dikembangkan oleh Emile Durkheim ${ }^{12}$ yang melihat pembangunan masyarakat sebagai

${ }^{9}$ Lebih jelas dapat merujuk kepada A.R. Hakim Aman Pinan, 1001 Pepatah Petitih Gayo (Takengon: Panitia Penerbitan Buku Adat dan Budaya Gayo, 1993), h. 36.

${ }^{10}$ Tengku H. Abdullah Husni, dalam Syukri, Sarakopat: Sistem Pemerintahan Tanah Gayo Dan Relevansinya Terhadap Pelaksanaan Otonomi Daerah (Jakarta: Hijri Pustaka Utama, 2006), h. 160.

${ }^{11}$ Abdurrahman Ali, "Peranan Islam Melaui Adat Gayo Dalam Pembangunan Masyarakat Gayo", dalam Makalah Seminar Ilmu Pengetahuan Dan Kebudayaan 20 - 24 Januari 1986 (Takengon: Diselenggarakan oleh MUI Provinsi Aceh dan MUI Aceh Tengah, 1986), h. 1.

${ }^{12}$ Durkheim was born in 1858 in the town of Efinal, near Strasbourg in north eastern France. His father was a rabbi, and as a young boy he was also strongly affected by a schoolteacher was 
suatu yang damai, maju, bergerak, berkembang, saling interaksi dan solidaritas sosial. ${ }^{13}$ Berdasarkan teori ini, penulis menggunakan teori Durkheim untuk melihat nilai-nilai pembangunan, adat dan agama dari sudut fungsinya. Di samping itu, teori Durkheim sangat signifikan untuk membangun masyarakat Gayo, karena salah satu faktor utama pembangunan masyarakat Gayo adalah tidak terlepas dari fungsi adat/budaya dan agama (Syariat Islam).

Di samping teori Durkheim, penulis juga menggunakan kerangka teori sosiologis dan antropologis yang dikemukan oleh Ibn Khaldun (w. 809/1406), ${ }^{14}$ yang berkaitan dengan fungsi organisasi masyarakat. Menurut teori Ibn Khaldun, organisasi masyarakat menjadi suatu keharusan bagi manusia (ijtimâ' darūrìyūn li an-nawâ 'al-insân). Tanpa orgnanisasi itu, eksistensi manusia tidak akan sempurna. Keinginan Tuhan hendak memakmurkan dunia dengan makhluk manusia, dan menjadikan mereka khalifah dipermukaan bumi ini tentulah tidak akan tebukti. Inilah arti yang sebenarnya dari nilai-nilai pembangunan dan peradaban ('ûmrân) yang dijadikan pokok pembicaraan ilmu pengetahuan yang selalu diperbincangkan atau didialogkan. ${ }^{15}$

Dengan demikian, kerangka teori yang dibangun dalam kajian ini meliputi dua bentuk. Pertama; menghubungkan nilai-nilai universal pembangunan masyarakat Gayo

Roman Catholic. These influences may have contributed something to his general interest in religious endeavors, but they did not make him personally a believer. By the time he was a yong man, he had become an a brilliant agnostic. Daniel L. Pals, Seven Theories of Religion (New York: Oxford University Press, 1996), h. 89-90. Artinya Durkheim lahir pada tahun 1858 di kota Epinal, dekat Strasbourg di Prancis sebelah Timur Laut. Ayahnya adalah seorang rabbi, dan ketika muda, ia juga sangat terpengaruh oleh guru sekolahnya yang beragama Katolik Roma. Pengaruh-pengaruh ini mungkin telah menyumbangkan sesuatu pada perhatiannya yang umum dalam usaha-usaha keagamaan. Namun, pengaruh-pengaruh itu secara pribadi tidak menjadikannya seorang yang beriman. Pada saat masih muda, ia telah menjadi seorang agnostik yang diakui.

${ }^{13}$ Emile Durkheim begitu terkesan oleh kemampuan agama dalam memelihara kesatuan sosial atau dalam menyatukan masyarakat (kelompok), sehingga ia membangun teori tentang agama sekitar itu. Ia melihat di balik keanekaragaman ritual, simbol dan kepercayaan agama terdapat karakteristik yang mendasari semua agama, dan berkesimpulan bahwa "the idea of society in the soul of religions". Lihat, Durkheim dalam L. Brom \& Philip Selzinic, Dorothy Darroch, Sosiology (New York: Harper \& Row Publisher, 1981), h. 399.

${ }^{14}$ Ibn Khaldun sangat dikagumi oleh kalangan intelektual dewasa ini di Timur dan di Barat, karena pemikiran-pemikirannya yang cermerlang, dituangkan dalam buku pengantar sejarahnya yang terkenal, Muqaddimah, bagian pertama bukunya yang berjilid-jilid itu, al-ibar. Tajam dan rasional meninjau masalah-masalah manusia dan sejarah, dengan analitik. Karena karya-karyanya itu dicatat dalam sejarah sebagai pendasar filsafat sejarah dan sosiologi. Dalam buku ini, selain kita perkenalkan kepada pribadi Ibn Khaldun, pemikir, sarjana dan ulama, diplomat dan politikus, dengan pengalaman-pengalamannya dari istana sampai ke markas militer, di Afrika Utara dan Spanyol, kita diperkenalkan juga kepada isi Muqaddimah dengan beberapa sorotan khusus yang berhubungan dengan pandangan pikiran dewasa ini mengenai beberapa masalah, yang sampai sekarang masih menjadi persoalan yang subur dan sering dibicarakan orang. Lihat, Ibn Khaldun, Muqaddimah, terj. Ahmadi Thoha (Jakarta: Pustaka Firdaus, 1986), h. 847.

${ }^{15}$ Lihat, Ibn Khaldun, Muqaddimah, h. 73. 
dalam bidang pembangunan fisik-material, yaitu bidang Infrastruktur, sosial budaya, ekonomi, lembaga pendidikan, sumber daya alam (SDA), lingkungan hidup, pemerintahan, kelembagaan dan hukum. Bentuk Kedua; menghubungkan nilai-nilai pembangunan masyarakat Gayo dalam bidang pembangunan moral-spiritual, yaitu aspek sistem nilai-nilai adat/budaya Gayo, yang meliputi Mukemel (Harga Diri), Tertib (Tertib), Setie (Setia), Gemasih (sayang), Mutentu (Kerja Keras), Amanah (Amanah), Mufakat (Musyawarah), Alang Tulung (tolongmenolong), dan Bersikekemelen (kompetitif). Kedua bentuk pembangunan tersebut dianalisis berdasarkan ajaran agama Islam sehingga nilai-nilai pembangunan masyarakat Gayo sesuai dengan pembangunan yang berlandarkan Islam.

\section{Sejarah Suku Gayo Di Indonesia}

Asal-muasal atau sejarah suku Gayo di Indonesia tidak dapat diketahui secara pasti, karena masih diselimuti oleh kabut misteri kerahasiaan. Dapat dikatakan masih belum terungkap dengan jelas, sebab di samping tidak memiliki data ilmiah yang akurat dan otentitik, serta kemungkinan karena tidak terlihatnya bukti-bukti sejarah suku Gayo ini, juga memiliki versi yang beragam dan tampaknya masih simpang siur tentang darimana asal-usul, kelahiran dan perkembangan mereka. Namun dilihat dari segi perjalanan waktu (historical approach), masyarakat suku Gayo di Indonesia tidak tiba-tiba muncul di kolong langit dunia ini, mereka pasti punya sejarah (the have a history) seperti kelompok etnik atau suku-suku lain di Nusantara ini, ${ }^{16}$ Seperti Suku Aceh, Batak, Jawa, Melayu, Minang dan Madura.

Dalam buku "Seri Informasi Aceh Tahun VI Nomor 4" tentang tinjauan selintas adat istiadat Gayo yang dikeluarkan oleh Pusat Dokumentasi dan Informasi Aceh tahun 1982 pada pengantarnya dikatakan bahwa; Sebagian besar penduduk Aceh terdiri dari bangsa Aceh, tahun 1980 berjumlah dua juta dari keseluruhannya, atau berjumlah 2.60.926 jiwa), sedangkan selebihnya adalah suku-suku bangsa lain, yakni suku bangsa bangsa: (a). Gayo yang mendiami Kabupaten Aceh Tengah (saat ini telah dimekarkan menjadi dua Kabupaten, yakni Aceh Tengah dan Bener Meriah). ${ }^{17}$ (b). Gayo Alas yang mendiami Kabupaten Aceh Tenggara (c). Tamiang (Teumiang) Gayo Seumamah dan Gayo Kakul (atau Kalul)

\footnotetext{
${ }^{16}$ Pengantar Usman Pelly, dalam, Syukri, Sarakopat: Sistem Pemerintahan Tanah Gayo Dan Relevansinya Terhadap Otonomi Daerah (Jakarta: Hijri Pustaka Utama, 2006), h. 2.

${ }^{17}$ Kabupaten Bener Meriah adalah hasil pemekaran Kabupaten Aceh Tengah pada 18 Desember 2003 yang lalu. Nama Kabupaten Bener Meriah ini diambil dari anak Raja Linge XIII yang bernama Bener Merie. Nama ini kemudian ditetapkan menjadi Nama Kabupaten Bener Meriah berdasarkan UU RI No. 18/2003 yang ditanda tangani oleh Menteri Dalam Negeri, DR. (Hc) Hari Sabarno, Sip, MBA, MM pada 18 Desember 2003, Lihat Profil Kabupaten Bener Meriah (Bener Meriah, Humas Setdakab, t.t), h. 2. Pada awalnya Kabupaten Aceh Tengah meliputi Alas Kota Cane, Belang Kejeren tetapi Kabupaten Aceh Tengah yang dahulu telah dimekarkan bebrapa Kabupaten yaitu, Kabupaten Aceh tenggara, Kabupaten Gayo Lues dan Kabupaten Bener Meriah.
} 
yang mendiami sebagian Aceh Timur. (d). Aneuk Jamee Singkil dan Kluet mendiami sebagian Aceh Selatan. (e). Simeulu (yaitu Defayan dan Sigule) yang mendiami sebagian Acah Barat. ${ }^{18}$

Dokumentasi di atas, jelas bahwa secara resmi, Departemen Pendidikan dan Kebudayaan Republik Indonesia 1981/1982, menyatakan bahwa Suku Gayo adalah suatu masyarakat atau kelompok etnik sendiri yang berbeda dengan kelompok atau etnik lain di Indonesia, khususnya kelompok etnik di Aceh, hal ini dapat dibuktikan dari segi bahasa, budaya suku Gayo dan lainnya, yang berbeda dengan suku-suku lainnya di Indonesia, termasuk dengan suku Aceh sendiri terdapat perbedaan yang sangat signifikan. Kelompok etnik Aceh merupakan kelompok etnik mayoritas di Provinsi Aceh bila dibandingkan dengan suku Gayo.

Walaupun kajian antropologi tentang asal-usul suku Gayo di Indonesia menurut pengetahuan penulis belum begitu jelas dan benar, tetapi ada beberapa literatur atau dokumentasi yang dapat dijadikan sebagai sumber rujukan keotentikannya. Di antaranya adalah dalam buku "Monografi Daerah Aceh Tengah 1981" bahwa Penduduk yang tergabung dalam suku Gayo, pada mulanya berasal dari Melayu Tua yaitu sejenis kelompok atau bangsa Melayu yang pertama mendiami kepulauan Indonesia. ${ }^{19}$

Berdasarkan sejarah bahwa setelah bangsa Melayu datang kedua kalinya ke kepulauan Indonesia, maka Melayu Tua yang sudah terlebih dahulu datang dan mendiami Indonesia sebahagian mereka mengalami assimilasi dengan berbagai suku-suku lain di Indonesia, dan sebahagian mereka lagi mendiami wilayah Aceh Tengah (Gayo Lut dan Gayo Darat), sebagaian wilayah Aceh Tenggara (Gayo Lues), dan sebahagian wilayah Aceh Timur (Gayo Sumamah atau Gayo Serbejadi dan Gayo Kalul). ${ }^{20}$

Wilayah-wilyah tersebut masih didiami oleh suku Gayo sampai sekarang. Namun dalam buku Monografi tersebut tidak dijelaskan kapan mereka mulai mendiami kepulaun Indonesia dan Aceh ini, pada abad keberapa, tahun berapa, siapa orangnya yang pertama

${ }^{18}$ Lihat. Departemen Pendidikan Dan Kebudayaan, Arsitektur Daerah Propinsi Daerah Istimewa Aceh, 1981/1982, h., 7, 12, 15.

${ }^{19}$ Monografi Daerah Aceh Tengah, (Banda Aceh: Fakultas Ekonomi Universitas Syiah Kuala, 1981), h. 10. Dalam Sumber lain bahwa "berdasarkan bukti sejarah setelah Melayu Tua pada 2.500 SM., datang ke Tanah Peurlak, kemudian 300 tahun menjelang Nabi Isa as, datang pula golongan Melayu Muda dari semenanjung Indo-Cina melalui pantai pesisir Timur dengan membawa pola dan cara kehidupan yang lebih baik. Tetapi golongan Melayu Tua tetap mempertahankan budaya dan adat-istiadat leluhurnya dengan tidak menerima budaya dan kebiasaan yang dibawa Melayu Muda. Sebelum Islam berkembang Melayu Tua segera menyingkir ke pedalaman dataran Tinggi Gayo, Tapanuli, Tanah Karo, Toraja Sumatera Selatan dan Pulau Nias. Melayu Tua menempati dataran Tinggi Gayo pada mulanya menempati daerah Samar Kilang dan kemudian sebagian menyebar ke kampung Seureule di Kacematan Bintang, kemudian mereka menyebar ke Gayo Lues dan Tanah Alas. Pada masa itu, di antara satu klien Melayu Tua dengan Klien lainnya belum bersatu dan masih di bawah pimpinan masing-masing klien, karena mereka memang belum menemukan sosok yang pantas menjadi pemimpin. Lebih rinci baca, H. R. Latief, Pelangi Kehidupan Gayo dan Alas (Bandung: Kurnia Bupa, 1995), h. 4.

${ }^{20}$ Latief, Pelangi, h. 1. 
mendiaminya, ini yang tidak ada dikemukakan dalam buku itu, sehingga menimbulkan pengkaburan sejarah, yang pada gilirannya kebenarannya diragukan. Hal ini juga tidak bisa disalahkan siapa-siapa, karena barangkali pada waktu itu belum ada ahli sejarah yang dapat mencatat dan membukukannya secara pasti, kalaupun ada ahli sejarah yang mencatat, kapan mereka mendiami kepulaun Indonesia sudah cukup lama sekali. Bahkan kalaupun sekiranya ada kelompok tertentu, apakah suatu badan, atau tim peneliti yang melakukan penelitian lebih lanjut tentang asal-usul suku etnik ini, sudah agak sulit dilacak atau ditemukan informasi-informasi yang akurat dan berdasarkan data-data yang otentik.

Bagi generasi muda Gayo sekarang harus bersyukur kepada Allah SWT., dan berterima kasih kepada para pendahulunya, sebab para pendahulu atau nenek moyang mereka telah bersusah payah mengukir dan merintis sejarah panjang mereka, sebahagian dari mereka ada yang telah dapat menulis dan menceritakan sejarah etnik ini secara turun temurun. Salah satu contoh misalnya bahwa menurut cerita turun-temurun dari nenek moyang etnik ini, menjelaskan bahwa orang Gayo di Indonesia pada mulanya bermukim di bagian Timur dan bagian Utara Aceh meliputi wilayah aliran sungai antara Sungai Temiang di sebelah Timur dan aliran Sungai Peusangan di Sebelah Barat.

Berabad-abad kemudian mereka pindah ke pedalaman menyusuri sungai-sungai yang ada, termasuk Sungai Jambu Ayee. Akibat pertambahan dan perkembangan penduduk, baik karena kelahiran maupun karena pendatang, guna mempeluas usaha pertanian. ${ }^{21}$ Pernyataan ini merupakan suatu cerita yang turun temurun dari mulut ke mulut atau dari mulut ke telinga, yang kadang-kadang cerita ini kemungkinan benar dan kemungkinan bisa salah, tapi inilah data sejarah yang sangat penting bagi generasi muda sekarang dalam mengetahui eksistensi sejarah etnik Gayo di Nusantara ini.

Meskipun cerita di atas dikemukakan berdasarkan cerita nenek moyang yang sifatnya turun temurun dari mulut kemulut atau dari mulut ketelinga, akan tetapi cerita di atas berkaitan dengan sumber lain, seperti yang ditulis oleh $\mathrm{H}$. Zainuddin dalam bukunya "Tarekh Aceh dan Nusantara" bahwa penduduk Peureulak yang tertua yang asalnya dari Melayu Tua pindah ke Seummah dan kemudian ke Serbajadi, Lingga (Linge) dan Nuzur (Isaq) melalui Sungai Peunarun. ${ }^{22}$

M.J. Melalatoa, dalam bukunya "Kebudayaan Gayo 1982" mengemukakan bahwa nenek moyang dari orang Gayo pergi menyusur sungai-sungai besar seperti Jambo Aer, pesangan, Sungai peurlak, Sungai Temiang, menuju kearah selatan. Ada di antara mereka yang lalu menetap di Hulu Sungai Peurelak, yaitu orang serbejadi, ada pula yang menetap

${ }^{21}$ Lihat, Ali Hasan Aman Kamalentan, 1970, dalam Mahmud Ibrahim, "Peranan Islam Melalui Adat Gayo Dalam Pembangunan Masyarakat Gayo" Seminar Ilmu Pengetahuan Dan Kebudayaan (Takengon: diselenggarakan MUI Aceh bekerjasama PEMDA/MUI Aceh Tengah, 1986), h. 2.

${ }^{22}$ Lihat, Zainuddin, Tarekh Aceh dan Nusantara, dalam Ibrahim, Peranan, h. 2. 
di Hulu Sungai Tamiang, yaitu orang Gayo Kalul. Kelompok lainnya menyusur Sungai Pesangan sampai ke hulunya di Danau Laut Tawar, ${ }^{23}$ sampai sekarang.

Sebagaimana dijelaskan sebelumnya bahwa bagi masyarakat Gayo sendiri, "zaman purbanya" 24 dikenal lewat cerita-cerita dari mulut ke mulut. Cerita semacam ini termasuk dalam kategori cerita rakyat,. Terutama dalam bentuk legende. Legende-legende itu sendiri biasanya berada dalam keragaman versi. Dalam berbagai tulisan dijelaskan bahwa orang Gayo adalah sekelompok orang yang tidak mau masuk Islam di daerah Pantai, kemudian mereka melarikan diri ke daerah pedalaman yaitu ke Hulu Sungai Peusangan, karena itu dikatakan "Kaiyo" (bahasa Aceh berarti takut atau melarikan diri), selanjutnya kata "Kaiyo" berubah menjadi sebutan "Gayo". ${ }^{25}$

Dari keterangan di atas. M.J. Melalatoa menjelaskan bahwa orang Gayo itu ada setelah agama Islam datang ke Aceh dan keterangan ini diambil dari hikayat Aceh. ${ }^{26}$ Apakah tidak ada kemungkinan karena orang Gayo itu lebih akhir mendapat pengaruh Islam itu, lalu dikatakan orang Gayo yang tidak mau masuk Islam. Kemungkinan lain ada orang Pesisir yang tidak mau masuk atau memeluk agama Islam, kemudian bergabung dengan orang Gayo yang belum dipengaruhi ajaran Islam tadi, jadi, bukan karena tidak mau masuk Islam, tetapi terlambat mendapat pengaruh Islam. Oleh karena hal ini masih perlu dipertanyakan, dikaji dan harus melakukan suatu penelitian yang serius dan sungguhsungguh. ${ }^{27}$ Sebenarnyalah orang-orang Gayo bukanlah melarikan diri karena takut masuk ajaran Islam, melainkan mereka hijrah atau pindah untuk mencari penghidupan yang lebih layak, patut, dan lebih sejahtera serta luas ke Samudra Pasai. ${ }^{28}$

${ }^{23}$ Lebih rinci dapat merujuk kepada M.J. Melalatoa, Kebudayaan Gayo, Seri Etnografi Indonesia No.1 (Jakarta: Penerbit Balai Pustaka, 1982), h. 35.

${ }^{24}$ Jaman Purba yang dimaksudkan disini adalah mulai dari jaman paleolitik sampai jaman perunggu. Batapakah masyarakat Gayo itu pada jaman tersebut. Kalau kita harus memberikan bukti-bukti tentang kebudayaan Gayo dari jaman itu, agaknya kita akan mengalami kesulitan. Kesulitan itu karena belum adanya penemuan-penemuan hasil Kebudayaan fisik (material culture) mereka, karena para ahli sendiri belum pernah melakukan penelitain. Lebih jelas lihat, Melalatoa, Kebudayaan, h., 35.

${ }^{25}$ Syahbudin, "Perasaran pada Seminar masuk dan Berkembangnya Islam di Aceh dan Nusantara di Peureulak Aceh Timur pada tanggal 25-30 september 1980, dalam Mahmud Ibrahim, Peranan, h. 2. Lihat Juga Zainuddin, Tarekh Aceh Dan Nusantara, h. 15; Said, 1961, h. 17; Team Monografi Daerah, 1975, h. 59-60, dan M.J Melalatoa, Kebudayaan, h. 35.

${ }^{26}$ Ketika sebuah angkatan dakwah Islamiyah berjumalah 100 orang yang terdiri dari orangorang Arab, Persia dan India dipimpin oleh Nakhoda Syahrir Nuwi dari Teluk Kambey Gujarat berlabuh di Teluk Perlak pada tahun $173 \mathrm{H}$ atau 800 M., orang-orang Gayo membaur dengan mereka dalam proses pemerintahan dan kemasyarakatan, diikat oleh tali persaudaraan Islam, pada waktu itu semua orang Gayo masuk Islam yang sebelumnya menganut animisme, Lihat H. Mahmud Ibrahim, Mujahid Dataran Tinggi Gayo (Takengon: Yayasan Maqamam Mahmuda, 2001), h. 19. Dari keterangan ini penulis berkesimpulan bahwa Islam masuk Ke Tanah Gayo sekitar tahun $173 \mathrm{H}$., atau tahun $800 \mathrm{M}$.

${ }^{27}$ Lihat, M.J. Melalatoa, Kebudayaan, h. 37.

${ }^{28}$ Lihat, Syukri, Sarakopat: h. 20. Mereka ini yang pada waktu itu hidup dari meramu dan 
Berdasarkan sejarah, sebenarnya orang Gayo sudah ada sejak pra Islam ${ }^{29}$ sesuai dengan pernyataan C. Snouck Hurgronje dalam bukunya "Het Gajoland en Zijne Beworners" menjelaskan bahwa orang Gayo ketika itu masih anamistis sudah Gayo namanya. Jadi, bukanlah timbul sesudah orang Batak diislamkan. ${ }^{30}$ Pernyataan C. Snouck ini selaras dengan pernyataan M.J. Melalatoa bahwa pada masa sebelum Islam, konon sudah ada suatu kerajaan di daerah Gayo sekarang yang bernama Kerajaan Linge. Kapankah kerajaan ini mula pertama berdirinya, kiranya tidak ada suatu keterangan yang pasti. Keteranganketerangan yang ada dari berbagai sumber tampak ada kesimpangsiuran. ${ }^{31}$ Kalau sekiranya Kerajaan Linge ini berdiri setelah Islam datang ke Tanah Gayo diperkirakan sekitar tahun 800 M., dalam sumber lain Kerajaan Linge ini berdiri pada abad V H. atau abad XI M., ${ }^{32}$ sudah tentu banyak ahli sejarah yang mencatat kapan berdirinya, tapi oleh karena kerajaan ini keterangannya masih simpangsiur dan beragam, maka dapat dipastikan berdirinya pada masa pra Islam datang ke Gayo.

Menurut Versi yang ditulis A.R. Hakim Aman Pinan dalam bukunya "Asal Linge Awal Serule" menunjukkan bahwa Kerajaan Linge ini berdiri pada zaman pra Islam, kendatipun Aman Pinan tidak menulisnya demikian, tapi yang jelas dimaksud Genali sebagai Raja Linge di sini adalah Genali pada zaman Roh Beldem. ${ }^{33}$ Genali adalah sebentuk pangkat atau gelar Anumerta, tidak sama dengan Genali yang tertera dalam "Silsilah Asal-Usul Keturunan Sultan Peurelak dan Linge Gayo" maksudnya lewat silsilah di atas adalah Meurah Ishaq ke Meurah Mersa, Meurah Mersa ke Meurah Jernang turun ke Adi Genali. ${ }^{34}$

berburu, terus mencoba mengembara (hijrah) dari satu tempat ke tempat yang lain dan terus ke Selatan lagi. Dalam pengembaraan ini ada yang menetap di sekitar Linge yang disebut Gayo Deret dan ada yang terus ke daerah Belangkejeren sekarang, dimana kemudian mereka lebih dikenal dengan Gayo Lues. Lebih jelas lihat M.J. Malalatoa, Kebudayaan, h., 35.

${ }^{29}$ Semenjak orang Gayo ada di Aceh Tengah sekitar tahun 617 SM, sudah memiliki adatistiadat, mereka pertama sekali berdiam di Perlak Pantai Timur Aceh dan Pase, kemudian menyusuri aliran Sungai Jambu Aye langsung ke Samarkilang, Serule, Linge (Isaq), kemudian Ke Takengon di lembah Sungai Danau Laut Tawar, Syukri, Sarakopat, h. 81.

${ }^{30}$ Keterangan di atas lebih rinci dapat merujuk kepada Hatta Hasan Aman Asnah, Gayo, Masyarakat dan Kebudayaan Awal Abad Ke 20, Terj. C. Snouck Hurgronje, "Het Gajoland en Zijne Bewornes" (Jakarta: Balai Pustaka, 1996), h. 45.

${ }^{31}$ Baca, M.J. Melalatoa, Kebudayaan, h. 38.

${ }^{32}$ Keterangan di atas lebih lanjut baca, H. Mahmud Ibrahim, "Peranan Islam Melalui Adat Gayo Dalam Pembangunan Masyarakat Gayo", Makalah Seminar Ilmu Pengetahuan dan Kebudayaan Tanggal 20-24 Januari 1986 (Takengon: Majlis Ulama Islam (MUI) Daerah Istimewa Aceh bekerjasama dengan MUI dan Pemerintahan Aceh Tengah, 1986), h. 30.

${ }^{33}$ Roh Beldem yang dimaksudkan barangkali adalah suatu kepercayaan animistis yang berkembang dalam masyarakat Gayo, di mana makhluk-makhluk halus atau roh-roh yang ada disekitar manusia, baik di hutan-hutan, di ladang, di kebun, di air, di pepohonan, di gunung-gunung, di rumah-rumah, di jalan-jalan, maupun di Istana Kerajaan Linge, Syukri, Sarakopat, h. 84.

${ }^{34}$ A.R. Hakim Aman Pinan, Asal Linge Awal Serule (Takengon: Pemerintah Daerah Kabupaten Aceh Tengah, 2002), h. 14. Menurut analisis penulis bahwa Kerajaan Linge di Tanah Gayo ada dua orang bergelar "Anumerta Genali" yaitu Pertama bernama Genali yang memimpin Kerajaan 
Perbedaan versi di atas, wajar dan lumrah sepanjang sejarah perkembangan pemikiran umat manusia, karena banyaknya sumber dan informasi-informasi yang beragam tentang sejarah Gayo. Akan tetapi, yang menjadi pertanyaan di sini adalah darimanakah asalusul Genali, ${ }^{35}$ yang disebut sebagai nenek moyang suku Gayo di nusantara ini. Ada lengende yang mengatakan bahwa orang Gayo pertama berasal dari "Negeri Rum”, orang itu adalah seorang laki-laki yang bernama Genali, terdampar kesebuah pulau kecil di kawasan Pulau Sumatera sekarang. Pulau kecil yang dimaksud adalah Pulau Sumatera sendiri yang ketika keadaannya belum sebesar seperti sekarang. ${ }^{36}$

Diceritakan bahwa Genali menikah dengan seorang putri raja yang sangat cantik jelita dari negeri Johor yang bernama "Putri Terus Mata", dari hasil pernikahan ini lahirlah keturunan mereka, kemudian tumbuh dan berkembanglah penduduk di Pulau Kecil ini, yang dinamakan dengan Pulau Buntul Linge, dan sebagai rajanya yang pertama adalah Genali sendiri dengan permaisurinya Putri Terus Mata. Di Pulau Buntul Linge inilah masyarakat Gayo semakin berkembang jumlahnya. Pulau tetangganya adalah bernama Serule. Ketika air laut menjadi surut kedua pulau itu menjadi satu. Oleh sebab itu, kalau membicarakan tentang asal muasal suku Gayo di Nusantara ini selalu disebut dengan "Asal Linge Awal Serule", artinya Linge dan Serule sama-sama asal dan sama-sama awal $($ asal $=$ awal), artinya Linge dan Serule mempunyai rakyat dan pemimipin sendiri.

Di Linge terkenal dengan Kerajaan Linge dengan raja pertamanya adalah Genali. Sedangkan di Pulau Serule juga mempuyai rakyat dan para pemimpin, Sebagai Perdana Menterinya yang pertama adalah Cik Serule. ${ }^{37}$ Sebenarnya asal dan awal itu adalah hampir bersamaan maknanya, namun demikian dijelaskan bahwa asal lebih dahulu ada barulah muncul awal, sebagai contoh umpamanya Tengku Rejewali lahir di Kebayakan, lalu ia hijrah ke Kampung Bintang, maka kampung Kebayakan adalah asal, sedangkan Kampung Bintang adalah awal.

Versi lain yang menuliskan bahwa asal-usul suku Gayo berasal dari Cina (Tionghoa), sebagaimana dikemukan Geniri, ahli sejarah yang menghubungkan Gayo dengan nama

Linge pada zaman pra Islam datang ke Linge, sesuai dengan versi yang ditulis oleh M.J. Melalatoa dan A.R Hakim Aman Pinan. Yang kedua Adi Genali sebagai Reje (Raja) Linge I atau ke-IV, ada setelah Islam datang ke daerah Linge Gayo sekitar tahun 416 H (1025 M.), sesuai dengan versi yang ditulis oleh H.A.R Latif dan A.Hasjmy. Lihat, Syukri, Sarakopat, h. $84-85$.

${ }^{35} \mathrm{Genali}$ adalah raja pertama yang berkuasa dan memimpin suku Gayo di Linge, menurut cerita rakyat Gayo bahwa Raja Genali tidak kelihatan jasadnya, kecuali suaranya saja yang dapat didengar. "Suaranya" dalam istilah bahasa Gayo disebut "Lengnge", kemudian berubah menjadi "Linge", itulah asal-muasal nama daerah Kerajaan Linge. Sedangkan istilah "Genali" berasal dari kata "Kenali", secara harpiah sama dengan "carilah", yang dimaksud dengan carilah adalah cari Lengnge (Suaranya).

${ }^{36}$ Lebih rinci lihat, M.J. Melalatoa, Kebudayaan, h. 36.

${ }^{37} \mathrm{Cik}$ Serule berasal dari Peureulak. Ia menikah di Serule dengan jenis perkawinan angkap (ikut isteri). Karenanya disebut asal Linge awal Serule, yang sebelumnya bernama Buniara. Permaisurinya bernama Putri Redum Maana. Lihat, Pinan, Asal, h. 42. 
"Dagroian" dari Marco Polo ${ }^{38}$ dan ia berpendapat bahwa kata itu singkatan dari "DrangGayu" yang dengan awal "Da" yang berarti "orang" dan "Gayu" yang berarti "Gayo". Jadi "Drang-Gayu" adalah orang Gayo. Malah Geniri mengatakan Nadur (Nagor) dalam beritaberita Tionghoa adalah negeri Gayo. ${ }^{39}$ Dari berbagai sumber dan keterangan-keterangan yang ada, baik dari Lengenda-lengenda atau cerita rakyat Gayo, maupun literatur-literatur yang telah dikemukakan di atas dapat dipahami bahwa suku Gayo di Nusantara ini, ada yang berasal dari Melayu Tua, ada juga yang berasal dari negeri Rum dan Johor, percampuran darah antara Genali dengan Putri Terus Mata, bahkan sebagian ada di antara mereka yang berasal dari Tionghoa.

Selanjutnya, Mahmud Ibrahim juga menuliskan dalam sebuah bukunya "Mujahid Dataran Tinggi Gayo 2001" bahwa orang Gayo datang dari Hindia Belakang ke kepulauan Nusantara ini pada gelombang pertama sebelum masehi. Mereka menetap di Pantai Timur Aceh dan sepanjang aliran Sungai Jambo Aye, Sungai Perlak dan Seruwe Kuala Simpang, mencari ikan, bercocok tanam dan berburu, mereka meyakini animisme..$^{40}$ Pernyataan Mahmud Ibrahim ini kelihatannya berbeda dengan tulisannya sebelumnya yang menjelaskan bahwa penduduk Peureulak yang tertua yang asalnyapun dari Melayu Tua pindah ke daerah Seumamah dan kemudian ke Serbejadi, Lingga (Linge) dan Nuzar (Isaq).

Perbedaan itu wajar, karena banyak sumber atau tulisan-tulisan yang ia kutip sebagai argumentasi tentang asal-usul suku Gayo di Nusantara. Kita sebagai generasi penerus harus dapat memilih dan memilah mana yang benar dan mana yang keliru, bahkan harus mampu menggali kembali keotentikan serajah Gayo ini yang sesungghunya. Meskipun ada perbedaan dan persamaan versi tentang kebenaran sejarah tentang asal-usul Suku Gayo di Indonesia, khususnya di Aceh. Kesemuanya itu kembali kepada Allah SWT., Sumber Segala Sumber Sejarah, Sumber Segala Ilmu Pengetahun, Dia-lah yang Maha Tahu, lagi Maha Mengetahui atas segala sesuatu, baik yang realitas maupun yang abstrak. Kelompok

${ }^{38}$ Menurut Dada Meuraxa yang ia kutip dari catatan perjalanan pengembara terkenal Marcopolo, ketika singgah di Peureulak, sekembalinya dari China ke Italia pada tahun 1292. Marcopolo menjumpai penduduk Peureulak telah memeluk agama Islam. Yang tidak mau memeluk agama Islam menyingkir ke pedalaman. Rakyat asli pedalaman menyebut daerahnya dengan "Lainggow" dan menyebut rajanya dengan Ghayo o Ghayo atau Raja Gunung yang suci. Lebih jelas baca, Pinan, Asal, h. 6.

${ }^{39}$ Keterangan di atas lebih rinci lihat, Zainuddin, “Tarikh Aceh Dan Nusantara”, h. 15.

${ }^{40}$ Ibrahim, Mujahid, h. viii. Istilah "animisme", dari kata Latin "anima" yang berarti jiwa. Dalam masyarakat primitive roh itu tersusun dari suatu zat atau materi yang "halus" sekali, yang dekat menyerupai uap atau udara. Dalam faham masyarakat primitif ini, roh itu makan, mempunyai bentuk dan umur. Bagi sebahagian masyarakat Gayo juga pada masa primitif menyakini dan mempercayai Roh-roh nenek moyang mereka, roh-roh itu diberi sesajen, berupa makanan, minuman dan lain sebagainya Salah satu ciri-ciri masyarakat Gayo primitif yang menganut kepercayaan animistis adalah menjaga kuburan orang meninggal selama beberapa hari dan membuat makanan untuk dimakan disana, kalau ada orang meninggal ditangisi beramairamai sambil meratap, dan mengadakan kenduri di kuburan orang-orang yang dianggap keramat. Lihat Kata Sambutan Tengku H. Moh. Ali Djadun, dalam Syukri, Sarakopat, h. 86. 
etnik Gayo memang merupakan salah satu kelompok etnik di Nusantara, dan dari segi populasi masyarakat Gayo jumlahnya sangat minoritas dan mendiami lokasi yang bergeografis pegunungan yang kurang strategis dari segi perdagangan dan perekonomian. Namun yang jelas, masyarakat Gayo punya sejarah dan saham sendiri dalam mengisi serta sebagai pelaku pembangunan bersama sebuah "nation state" yang bernama Negara Kesatuan Republik Indonesia bekas territorial kolonial Belanda dan Jepang.

\section{Nilai Nilai Pembangunan Suku Gayo}

Dalam suatu masyarakat lazimnya memiliki sistem nilai yang dapat dirinci menjadi; nilai adat-istiadat, budaya, nilai pengetahuan, nilai religi, ${ }^{41}$ Secara kronologis ada beberapa sistem nilai adat yang dijadikan upaya membangun masyarakat Gayo yang lebih maju, sejehtera dan bermartabat, yaitu:

\section{Mukemel (Harga diri)}

Di masa lalu masyarakat Gayo telah merumuskan prinsip-prinsip adat yang terkenal dengan sebutan "kemalun ni edat" (pantangan adat). Nilai atau prinsip adat itu menyangkut "harga diri" (kemel = malu) yang harus dijaga, diamalkan, ditegakkan, dan dipertahankan oleh kelompok kerabat tertentu, kelompok satu rumah (sara umah), klen (belah), dan kelompok yang lebih besar lagi. Prinsip adat itu, meliputi empat hal sebagai berikut; ${ }^{42}$

a. Malu tertawan (wanita ditawan orang) maksunya adalah harga diri yang terusik karena kaum wanita dari anggota kelompoknya diganggu atau difitnah kelompok lain, atau anak perempuan dilarikan dan ditawan oleh orang atau kelompok dari klen lain.

b. Bela mutan (pembelaan digagalkan orang) sehingga seseorang tidak dapat lagi membela atau memulihkan haknya.

c. Negeri terpencang (Negeri diganggu orang) wajib dipertahankan, yakni harga diri yang menyangkut hak-hak atas wilayah wajib dijaga.

d. Nahma teraku (penghinaan, dan merusak nama baik) harus dipulihkan dan dibela, sehingga nama baik kedaulatan, bangsa, masyarakat, keluarga serta perorangan tetap terpelihara, dengan demikian harga diri yang menyangkut kedudukan tetap sah. ${ }^{43}$

${ }^{41}$ Wawancara dengan Tgk. H. Mohd Ali Djadun, Ketua Majelis Permusyawaratan Ulama (MPU) Aceh Tengah, pada Sabtu, 04 Pebruari 2012 di Takengon.

${ }^{42}$ Mahmud Ibrahim, "Peranan Islam Melalui Adat Gayo Dalam Pembangunan Masayarakat Gayo" dalam Makalah Seminar Ilmu Pengetahuan Dan Kebudayaan 20 - 24 Januari 1986 (Takengon: Diselenggarakan oleh MUI Provinsi Aceh bekerjasama dengan Pemda dan MUI Kabupaten Aceh Tengah, 1986), h. 4.

${ }^{43}$ Wawancara dengan H. Mahmud Ibrahim, Wakil Ketua MPU Kebupaten Aceh pada Minggu, 05 Februari 2012 di Kantor MPU Kabupaten Aceh Tengah di Takengon. 
Berdasarkan empat prinsip di atas, maka seorang individu dalam masyarakat Gayo harus menegakkan dan menjaga "harga diri"nya. Karena orang yang punya "harga diri" di sebut "mukemal"artinya "punya rasa malu". Sebaliknya orang yang tidak punya rasa malu adalah orang yang tidak punya harga diri yang disebut "gere mukemal" atau "tidak mempunyai rasa malu" yang dipandang rendah oleh masyartakat adat itu. Jadi, "mukemel" (harga diri) adalah sebuah nilai utama atau nilai yang paling penting dalam masyarakat Gayo. ${ }^{44}$ Nilai-nilai yang terkandung dalam mukemel merupakan suatu nilai yang menjadi acuan bagi tingkah laku atau tindakan dalam berbagai aspek kehidupan masyarakat Gayo.

\section{Tertib (Tertib)}

Tertib sebagai salah satu sistem nilai adat-istiadat dan budaya masyarakat Gayo mesti dipelihara dan dipertahankan. Sebagaimana dimaklumi bahwa, tertib sama artinya dengan teratur, menurut aturan, atau rapi. ${ }^{45}$ Apapun yang kita lakukan dituntut tertib menjadi pegangan. Antara tertib dan disiplin adalah erat sekali hubungannya. Bila tertib tidak dilakukan, sama halnya dengan centang perenang, semua kegiatan tidak terarah yang pada akhirnya mengalami kegagalan atau tidak berhasil. Karena itu, dalam tertib, mengandung nilai, gagasan, konsepsi, norma, hukum yang bersamaan. ${ }^{46}$ Dengan demikian, semua nilai-nilai yang terkandung dalam tertib di atas dapat dijadikan sebagai acuan bagi segala tindakan dalam berbagai aspek hidup dan kehidupan masyarakat Gayo.

Dalam pribahasa Gayo nilai tertib ini diungkapkan dalam kalimat: "Tertib bermajelis, umet bermelie" (Teratur dalam kebersamaan, akan memuliakan umat). ${ }^{47}$ Ungkapan lain yang berkaitan erat dengan nilai tertib adalah "Setie mate gemasih papa" (Biar mati demi kesetiaan, biar papa demi kasih sayang). Kita dapat kiranya memahami betapa tingginya harga nilai tertib, kesetiaan dan kasih sayang dalam kebudayaan Gayo ini. ${ }^{48}$ Jelasnya, tertib selalu berada setiap waktu yang mengeliling kita. Berbicara perlu tertib, berjalan, makan dan minum, ke masjid, ke menasah, ke sekolah, lalu lintas, bergaul, berpakaian,

${ }^{44}$ Keterangan lebih rinci lihat, M.J. Melalatoa, "Budaya Malu: Sistem Budaya Gayo" dalam Sistem Budaya Indonesia (Jakarta: Diterbitkan atas Kerjasama Fakultas Ilmu Sosial dan Ilmu Politik Universitas Indonesia dengan Penerbit PT. Pelajar, 1997), h. 203.

${ }^{45}$ Wawancara dengan Khairussaleh, Kepala Kampung Kala Lengkio Kecamatan Kebayakan, tanggal, 05 Februari 2012 di Takengon.

${ }^{46}$ A.R. Hakim Aman Pinan, Hakikat Nilai-Nilai Budaya Gayo Aceh Tengah (Banda Aceh: Diterbitkan Oleh Pemerinrtah Daerah Kabupaten Aceh Tengah, 1998), h. 70.

${ }^{47}$ Pribahasa Gayo di atas, dalam sumber lain dimaksudkan adalah "perlunya tertib dalam Dewan atau rapat yang mengemban tugas atau pertemuan orang banyak, rapat, berhimpun untuk membicarakan sesuatu hal. Berkumpul seperti ini dipandang pekerjaan yang paling mulia. Dalam hidup dan kehidupan ini, tertib itu adalah modal pokok. Tertib itu berlaku disegala masalah, serta berlaku kepada siapapun. Dilihat dari pandangan adat, bila tidak tertib bisa saja sesewaktu menjurus pada pantangan adat, bila sempat terjadi tentu saja mengandung keresahan masyarakat, dan bukan tidak mustahil akan menerima sanksi adat yang berlaku. Lihat, Pinan, Hakikat, h. 70 .

${ }^{48}$ Baca, M.J. Melalatoa, Budaya, h. 204. 
bertamu dan ke kantor harus tertib. Bahkan menghadapi orang tua, guru, dan kesenian mesti tertib. Karena itu, tertib ini mengandung nilai-nilai penting dalam membangun masyarakat Gayo.

\section{Setie (Setia)}

Setie (setia) adalah salah satu faktor yang sangat penting dalah hidup berkeluarga, bermasyarakat, berbangsa dan bernegara, termasuk diutamakan belah (klein) dan beragama. Tanpa setie jelas masyarakat, dan kelompok tidak akan mencapai hasil yang maksimal. Dalam pribahasa Gayo diseburtkan bahwa: "Setie murip gemasih papa". ${ }^{49}$ Artinya kesetiaan hidup karena kasih sayang, walaupun hidup itu merana. Kesetiaan yang dimotivasi oleh rasa kasih sayang, menyebabkan orang suka berkurban, baik fikiran, tenaga maupun harta dan jiwa, walaupun berakhir dengan kepapaan atau kemiskinan. Perasaan sosial bagi orang yang menghayati dan melaknakana nilai ini amat tinggi, karena mereka menyadari bahwa manusia adalah makhluk sosial, tidak mungkin ia bisa hidup sendirian untuk meraih kesejahteraan dan kebahagian hidup di dunia. Mereka harus setia, seia dan sekata dalam mencapai satu tujuan hidup.

\section{Semayang/Gemasih (Kasih sayang)}

Dalam peribahasa masyarakat Gayo dinyatakan bahwa: "Kasih enti lanih, sayang enti lelang". Artinya bila kasih janganlah terlambat, andaikan sayang jangan pula setengah hati, ${ }^{50}$ Dalam hakikat budaya Gayo kata semayang/gemasih (kasih sayang) ${ }^{51}$ adalah merupakan ciri khas yang perlu dipertahankan dan dilestarikan dalam membangun masyarakat Gayo yang lebih maju, sejahtera dan bermartabat. Realisasi daripada semayang/gemasaih (kasih sayang) kepada orang lain tepat pada waktunya, adalah kasih sayang yang sejati dan abadi serta amat berguna bagi orang yang dikasihi, kendatipun tanda kasih dan sayang itu tidak begitu banyak dan mendalam. Namun pembuktian kasih sayang yang dilakukan pada waktunya adalah bentuk kasih sayang yang paling sempurna. Sebaliknya kasih sayang yang tidak tepat waktunya, sering mengakibatkan bencana, seperti terlalu memanjakan

\footnotetext{
${ }^{49}$ Lebih rinci lihat, Pinan, Hakikat, h. 78.

${ }^{50}$ Peribahasa Gayo di atas lebih jelasnya baca, A.R. Hakim Aman Pinan, 1001 Pepatah Petitih Gayo (Takengon: Panitia Penerbitan Buku Adat dan Budaya Gayo, 1993), h. 68.

${ }^{51}$ Makna semayang/gemasih (kasih sayang) disini tentu relatif luas. Penempatan makna (meaning) bergantung kepada sipemakainya. Maksudnya, kasih sayang pada kedua orang tua (ibu dan bapak) bentuknya lain bila dibanding dengan kasih sayang pada orang miskin yang membutuhkan pertolongan. Kasih sayang pada teman, sangat berbeda dengan kasih sayang kepada orang yang bukan teman, kasih sayang pada seorang isteri dan anak-anak sendiri sangat beda dengan kasih sayang kepada istri dan anak-anak orang lain. Oleh karena itu, kasih sayang itu sangat relatif dan subjektif bagi orang yang memilikinya. Wawancara dengan Tgk. H. Mohd. Ali Djadun, pada 21 Februari 2012 di Takengon.
} 
anak, membantu orang lain dalam jumlah yang sangat besar, tetapi dilakukan dengan sombong dan congkak, hal itu tidak dibenarkan dalam adat masyarakat Gayo, karena bertentangan dengan nilai adat Gayo itu sendiri. ${ }^{52}$

\section{Mutentu (berdaya guna /kerja keras)}

Mutentu adalah salah satu nilai yang amat penting dalam membangun masyarakat Gayo, karena mutentu adalah pedoman yang baik dan berguna bagi siapa saja. ${ }^{53}$ Mutentu dapat juga diartikan terkendali, sifat mutentu, lebih diarahkan pada setiap pribadi seseorang. Dalam masyarakat Gayo, jika ada sesorang remaja atau gadis yang mutentu sangat disenangi dan dihormati oleh masyarakat, dan lazimnya akan segera dipinang orang. Di samping itu, makna dari mutentu dalam adat masyarakat Gayo adalah rajin atau bekerja keras serta sangat rapi dalam melakukan atau mengerjakan sesuatu. ${ }^{54}$ Sebaliknya bagi orang yang tidak rajin, tidak giat bekerja keras (gere mutentu) tidak akan dihormati dan tidak disenangi oleh masyarakat, sehingga bagi orang-orang yang tidak memperdulikan nilai mutentu, maka akan menyebebkan nilai-nilai lain seperti yang telah dikemukan di atas, sangat sulit untuk dapat dia hayati dan diwujudkan dalam setiap prilakunya dalam kehidupan sehari-hari.

\section{Amanah (Amanah)}

Salah satu dari hakikat budaya Gayo adalah melaksanakan amanah, ${ }^{55}$ sebagaimana dalam pribahasa Gayo dinyatakan bahwa: "Kukur amat tergukkee, akang amat terbekase, jema amat terlinge". Maksudnya burung itu diketahui benar adalah burung balam, setelah didengar akan suaranya, rusa dapat dilihat sebagai bukti ialah bekas kakinya. Sedangkan orang baru dapat dipandang amanah apabila selalu terbukti keabsahan segala perkataannya, perbuatannya, tingkah lakunya. Sejalan perkataan dengan perbuatan. Bila umpamanya tidak sesuai perkataan dengan perbuatan, maka jelas orang ini tidak amanah. Dalam pri bahasa Gayo terkenal dengan istilah: "Nangka ipenangka, nangka ibaruli, kata ipekata,

${ }^{52}$ Penulis melakukan wawancara dengan Tgk. H. Mahmud Ibrahim, pada hari Sabtu, 04 Februari 2012 di Tekengon Kabupaten Aceh Tengah.

${ }^{53}$ Keterangan di atas lebih rinci lihat, Pinan, Hakikat, h. 82.

${ }^{54}$ Istilah mutentu di sini dapat mengandung arti bahwa seseorang mampu menempatkan berbagai peroblema atau persoalan dalam arti siap menangani segala kemungkinan yang datang. Romantika hidup silih berganti, antara suka dan duka. Suka diterima dengan rasa syukur, apabila menemukan duka juga diterima dengan rasa sabar dan tawakkal. Lebih rinci baca, Pinan, Hakikat, h. 82 .

${ }^{55}$ Dalam adat Gayo menurut pandangan A.R. Hakim Aman Pinan, bahwa maksud amanah ialah yang dipercayakan (dititipkan) kepada orang lain. Kemerdekaan Indonesia merupakan amanah daripada pahlawan bangsa. Mengamanahkan, mempercayakan, saudagar menitipkan hartanya kepada saudaranya. Beramanat, berpesan, adalah menyampaikan amanah. Lihat, Pinan, Hakikat, h. 67. 
kata ilalui". Maksudnya perkataannya selalu berbelit belit, dan ia sendiri yang menodai perkataannya itu kembali, atau dengan kata lain, perkataan dengan perbuatannya tidak searah. Pada lazimnya pribahasa ini lebih menjurus pada mereka yang tergolong pemuka masyarakat yang tidak menjalankan amanah dengan baik. Hal ini tentu wajar-wajar saja, bila disebut pemuka, ulama, atau tokoh masyarakat mesti sama fungsi dan peranannya sebagai panutan masyarakat yang harus amanah, jujur dan bertanggungjawab. ${ }^{56}$

\section{Genap Mupakat (Musyawarah)}

Di samping nilai-nilai yang telah disebutkan di atas, maka nilai-nilai pembangunan masyarakat Gayo yang disebut "Genap Mupakat" (musyawwarah) termasuk nilai yang amat penting dalam pembangunan masyarakat Gayo. Sebab apa yang telah dimusyawarahkan dan telah diputuskan dalam musyarawarah, harus dipegang teguh dan dilaksanakan secara konsisten (îstîqâmâh).

\section{Alang Tulung Berat Bebantu (Tolong menolong)}

Dalam bahasa suku Gayo, ada istilah "Alang tulung, beret berbantu” mengandung prinsip melakukan kegiatan secara bergotong royong. Pengertian "alang" adalah rebah (tidur) "ku a.lang, an mulo ku umah rinung so" (kutidurkan saja diriku ke kamar itu). ${ }^{57}$ Namun yang dimaksudkan a.lang dalam kajian ini, adalah apabila ada suatu pekerjaan yang sangat berat, maka pekerjaan itu harus dikerjakan secara bersama-sama, dan yang mempunyai pekerjaan tersebut harus menyerahkan (merebahkan) beban berat yang dipikulnya kepada keluarga, atau masyarakatnya, sehingga beban atau pekerjaannya yang berat tadi terasa sangat ringan, dan mudah karena telah dikerjakan secara bersama-sama atau gotong royong dan penuh rasa tanggungjawab serta konsisten. Makna bertolong- tolongan dalam masyarakat suku Gayo Indonesia ini adalah dalam hal yang positif, bukan negatif, yakni kebaikan dan takwa bukan dosa dan permusuhan.

Sedangkan pengertian "tulung" (tolong) adalah mengharapkan bantuan dari orang lain, apakah teman, keluarga, atau masyarakat, sehingga beban berat yang dipikulnya terasa ringan, misalnya "anak oya ne nge nguk kin tulung'. (anak itu sudah dapat meringankan beban). Muniro tulung (meminta bantuan). Jadi, kata "tulung" sinonim dengan bantuan, bahasa Gayonya disebut "bebantu". Kata "beret" (berat). Makna berat dalam bahasa Gayo sangat beragam dan bervariasi. Dalam "Kamus Bahasa Gayo" dijelaskan bahwa "be.ret (berat): - tulung (ki) orang yang sifatnya tidak lincah dan malas; - ate, tidak sampai

\footnotetext{
${ }^{56}$ Penulis melakukan wawancara dengan Tgk. Khaliluddin, Imam Besar Masjid Al-Abrar Kebayakan, pada tanggal, 04 Februari 2012 di Aceh Tengah,Takengon.

${ }^{57}$ Baca, M.J. Melalatoa, Kamus Bahasa Gayo-Indonesia (Jakarta: Pusat Pembinaan Dan Pengembangan Bahasa, Departemen Pendidikan dan Kebudayaan, 1985), h. 4.
} 
hati; anak turah kin - ringen ini ine-ama, e (seorang anak harus menjadi penolong orang tuanya; reta - barang berharga; si-ni mata (ki), orang yang disegani dan dihormati menurut ketentuan hukum adat/budaya masyarakat Gayo, (misalnya, adab seseorang terhadap mertuanya, dua orang bersaudara yang berlainan jenis kelamin); ton ni umahe tengah —, istrinya sedang hamil; — kerejene (ki), orang yang sukar berubah nasibnya (misalnya ada seorang perempuan yang tidak mau dipinang orang)" ${ }^{58}$ Dengan demikian, "alang tulung berat bebantu" mengandung makna adalah, tolong menolong dalam melakukan pekerjaan yang berat. Mu.bantu (membantu); Wan nya-nya jarang we ara jema si mera mu bantu,e" (dalam kondisi kesusahan jarang ada orang membantunya). ${ }^{59}$

\section{Besikekemelen (Rasa malu/harga diri)}

Di samping beberapa nilai budaya Gayo yang telah dikemukakan di atas, maka budaya bersikekemelen mempunyai nilai yang sangat penting dalam masyarakat Gayo. Karena keseluruhan dari tatatan kehidupan masyarakat Gayo tersimpul dalam suatu kelompok yang padu disebut "satu kesatuan harga diri" (sara kekemelen). Pelangganggaran atas prinsip adat ini akan mempengaruhi tindakan anggota suatu kelompok dalam mempertahankan prinsip-prinsip. Harga (kemel) diri adalah sebuah nilai. Bahkan dapat disebut nilai utama atau nilai yang dipandang paling urgen. ${ }^{60}$ Dalam keseluruhan sistim nilai dalam masyarakat suku Gayo Indonesia.

Setiap orang atau pun individu dalam masyarakat Gayo harus berani berkorban, meskipun dengan darah dan nyawa sekalipun demi tegaknya harga diri itu. Hal ini tercermin dalam ungkapan adat Gayo: "Ike kemel mate" (Kalau sudah malu lebih mati). Namun tindakan adat yang mungkin menyimpang jauh akan dikontrol dan dikendalikan oleh kaidah-kaidah agama (hukum) ${ }^{61}$ Oleh karena itu, setiap orang dalam masyarakat Gayo harus menegakkan dan menjaga "harga diri". Orang yang mempunyai "harga diri" disebut dengan "mukemel" artinya mempunyai rasa malu. Sebaliknya orang yang tidak mempunyai rasa malu disebut "gere mukemel" atau tidak mempunyai rasa malu yang dipandang oleh masyarakat adat.

\section{Nilai-Nilai Budaya Gayo Dalam Perspektif Islam}

Nilai-nilai pembangunan dalam masyarakat Gayo sebagaimana yang telah dikemukakan di atas sangat positif dalam pandangan Islam, Karena adat dan budaya itu lahir

${ }^{58}$ Lihat, Melalatoa, Kamus, h. 34.

${ }^{59}$ Penulis melakukan wawancara dengan Bapak Ibn Hajar Laut Tawar pada hari Minggu, 05 Februari 2012 di Aceh Tengah Takengon.

${ }^{60}$ Lihat, M.J. Melata Toa, "Budaya" dalam Sistem, h. 203.

${ }^{61}$ Keterangan di atas diperoleh melalui wawancara dengan Tgk. Mahmud Ibrahim, pada hari Minggu, 05 Februari 2013 di Takengon. 
dari renungan para ulama. ${ }^{62}$ Pentingnya ulama tersebut terletak pada peranan mereka dipandang sebagai penafsir-penafsir legimetate dari sumber-sumber asli ajaran Islam. karena itu, peran ulama dalam melahirkan nilai-nilai adat dan budaya sangat penting dan menentukan bagi pembangunan masyarakat Gayo.

Nilai-nilai pembangunan masyarakat Gayo berasal dari dua sumber utama, yaitu: Pertama; bersumber dari para leluhur mereka yang bermuatan ilmu pengetahuan, keyakinan, nilai-nilai, norma-norma. Kesemuanya disebut "resam". Kedua; bersumber dari agama Islam yang dibawa oleh para ulama berupa akidah, ibadah, muamalah, akhlak dan kaedahkaedah agama lainnya yang disebut "hukum". Dalam fakta dan kenyataannya bahwa apa yang berasal dari kedua sumber nilai-nilai adat Gayo dan hukum Islam itu sepertinya sudah menyatu, berjalin dan berkelindan sedemikian rupa sehingga tidak dapat dipisahkan antara satu dengan yang lainnya. Dengan kata lain nilai-nilai pembangunan dalam adat Gayo tidak bisa lekang dari hukum Islam. Beberapa contoh ungkapan adat Gayo berikut ini menunjukkan keterjalinan itu yaitu; "Ukum Ikadung edet, edet ikadung ukum”. Artinya setiap hukum adalah mengandung adat, dan setiap adat mengandung hukum. Dalam kata adat Gayo yang lain disebutkan bahwa "agama ibarat empus, edet ibarat peger". Artinya agama Islam laksana kebun, adat laksana pagar. ${ }^{63}$ Jadi, adat mencari tata kelakuan yang dibutuhkan dan melaksanakannya, lalu dikontrol dengan aturan agama. Hal ini dituangkan dalam ungkapan adat Gayo bahwa: "Edet mungenal, hukum Islam mubeza". Artinya adat yang kuat menyebabkan terpelihara agama, adat yang lemah merusak nama baik, dalam bahasa adat Gayonya diungkapkan bahwa: "Edet kuwet muperala agama, rengang edet benasa nama. Edet munukum bersifet ujud, hukum munukum bersifet kalam". Artinya adat itu berjalan dituntun oleh hukum agama. Adat tidak kuat binasa nama. Adat menghukum bersifat wujud. Hukum agama itu adalah pasti keotentikannya sebagai wahyu Allah SWT. ${ }^{64}$

Lebih lanjut tentang hubungan hukum adat dengan hukum agama sebagaimana dijelaskan oleh Tengku H. Abdullah Husni dalam buku Sarakopat, bahwa hukum adat dan adat istiadat menghukum bersifat wujud, artinya kata adat itu selaras dengan hâbâlûmmînnâllâh. Falsafah hukum adalah adat. Maksudnya adalah adat istiadat itu tidaklah akan kuat dan kokoh kalau sekiranya tidaklah bersumber kepada hukum syârâ', dan hukum syârâ tidaklah akan terwujud dan terealisasi serta menjadi suatu kenyataan dalam pembangunan masyarakat Gayo, kalau tidak dijadikan adat dengan hukum agama tidak dapat dipisahkan, sebagaimana dalam ungkapan adat masyarakat Gayo "Syariat urum edet,

${ }^{62}$ Dimaksud ulama dalam kontek ini adalah orang-orang yang mempunyai pengetahuan tentang ayat-ayat Allah SWT., baik yang bersifat kauniyah maupun Quraniyah, dan dengan pengetahuannya tersebut mereka dapat mencapai tingkat khasyyah kepada Allah SWT. Lihat, Warul Walidin, AK, et.al, Peranan Ulama Dalam Pelaksanaan Syariat Islam Di Provinsi Nanggroe Aceh Darussalam (Banda Aceh: Pemerintah Daerah Provinsi Nanggroe Aceh darussalam, 2006), h. 11.

${ }^{63}$ Lihat kata-kata adat Gayo dalam Syukri, Sarakopat, h. 159.

${ }^{64}$ Keterangan di atas dapat merujuk kepada A.R. Hakim Aman Pinan, 1001 Pepatah Petitih Gayo (Takengon: Panitia Penerbit Buku Adat dan Budaya Gayo, 1992), h. 36. 
lagu zet urum sifet". Artinya syariat dengan adat laksana zat dengan sifat. ${ }^{65}$ Karena itu, pandangan Islam terhadap nilai-nilai pembangunan masyarakat Gayo merupakan faktor penentu terhadap terpeliharanya identitas dan tegaknya pembangunan. Adat dan syariat jika diamalkan secara padu dan îstîqâmâh, akan menunjang pelaksanaan pembangunan di segala bidang. Sebab keterpaduan nilai adat dan syariat memperkokoh iman, takwa, dan mempererat kesatuan bangsa.

Karena adat istiadat Gayo ini diperankan oleh para ulama masa dahulu kala maka sudah logislah bahwa sembilan sistem nilai dalam budaya Gayo yang telah diuraikan di atas itu adalah bahagian dari ajaran Islam. Pertama, mukemel (harga diri) yang muncul dari budaya malu (âlhâyâ), yang merupakan manipestasi dari iman. Malu adalah sifat individu yang dapat menjadi benteng untuk melakukan kemungkaran. Orang Gayo tidak pernah menjadi pengemis di pinggir jalan meskipun ia buta dan cacat, mereka malu melakukan kejahatan dan kemungkaran bahkan melanggar adat. Kedua, Tertib (tertib) adalah sikap rakyat Gayo yang teratur baik dalam beribadah, bermasyarakat bahkan bekerja, dalam pertanian misalnya sudah ada "keujurun belang" ${ }^{66}$ yang mengatur tata cara bertani. Ajaran Islam menghendaki tertib dan teratur sehingga rukun salat yang terakhir adalah tertib. Ketiga, Setie (setia dalam kebersamaan), merupakan ajaran Islam yang berasal dari silaturrahim yang dalam mayarakat Gayo selalu setia dalam bekerja sama baik membangun rumah, jembatan, Masjid dan membantu mengerjakan sawah atau kebun secara bergiliran (mango lao), mahlat (mengundang pemuda pemudi dari desa lain untuk bekerja), menempuh (membantu), berjamu (gotong royong), ${ }^{67}$ semangat kebersamaan dari hubungan persaudaraan ini, tentu berasal dari nilai al-Qur'an. Keempat, semayang atau gemasih (kasih sayang), yang dalam Islam disebut ûkhûwâh îslâmîyâh yang diimplementasikan dalam melaksanakan hak sesama muslim yang saling kasih mengasihi terutama ketika ada saudaranya yang sakit, musibah mereka saling membantu. Di antara bentuk memenuhi hak seorang muslim juga adalah selalu berbaik sangka kepada mereka, tidak mematamatai gerak geriknya, tidak dengki, tidak memarahinya, mencurahkan rasa persahabatan. ${ }^{68}$ Kelima, mutentu (berdaya guna), adalah sifat orang Gayo yang selalu menolong dan mem-

\footnotetext{
${ }^{65}$ Tengku H. Abdullah Husni, Seorang Tokoh Ulama dan Petue (Petua) Kampung Kala Lengkio Kebayakan dalam Syukri, Sarakopat, h. 16.

${ }^{66}$ Kejurun Belang ialah lembaga adat yang mengatur sirkilasi kegiatan pertanian khususya petani padi atau berume (bersawah) dialah yang merencanakan program bersawah mulai dari menyemai, menam sampai panen. Beliau selalu mengumumkan hal-hal bertani kepada rakyat dengan berkeliling kampung dengan membunyikan gong (induk alat musik gamelan). Instruksi yang disampaikan mesti ditaati oleh masyarakat, jika dilanggar akan menimbulkan akibat bagi pertanian itu, seperti hama dan gagal panen.

${ }^{67}$ Melalatoa, Kebudayaan Gayo (Jakarta: Balai Pustaka, 1982), h. 132

${ }^{68}$ Hak seorang muslim kepada muslim lainnya dalam sebuah hadis Rasulullah SAW. Ada lima: membalas salam, menengok yang sakit, mengantarkan jenazah, memenuhi undangan, dan mendoakan orang yang bersin. (HR. Bukhari Muslim), Lihat Said Hawa, Al-Islam (Jakarta: Gema Insani, 2004), h. 103-401.
} 
beri manfaat bukan hanya sesama manausia tapi juga kepada lingkungan sekitarnya bahkan kepada hewan sekalipun. Maka tidak heran masyarakat Gayo memilki hewan peliharaan seperti kuda, kerbau, lembu, kambing, ayam, itik dan lainya yang diperlakukan secara baik. Sikap ini tentu disemangati oleh ajaran Islam yang memelihara lingkungan. Keenam, Amanah adalah salah satu dari nilai Islam yang mesti dilaksanakan oleh seorang muslim, dan salah satu sifat wajib dari Rasulullah SAW. adalah âmânâh yang sejak kecil baginda Nabi sudah digelar dengan al-amin orang yang amanah (jujur) ${ }^{69}$ Wajar saja masyarakat Gayo menjadikan amanah sebagai salah satu sistem nalai dalam budayanya. Ketujuh, genap mupakat (musyawarah) bagi orang Gayo adalah sebuah keniscayaan dalam berbagai kegiatan yang disebut (kamul atau murum) baik dalam perkawinan, sunatan, kelahiran bahkan musibah mereka mengutamakan musyawarah dan mufakat. Dalam Islam, musyawarah merupakan sendi kehidupan sehingga musyawarah dapat menyelesaikan berbagai masalah sehingga menimbulkan kenyamanan dan keselamatan (Q.S.3: 159). Kedelapan, alang tulung berat berbantu (saling tolong menolong) juga merupakan sendi ajaran Islam yang menganjurkan umat Islam membantu satu sama lain (Q.S.5: 2). Kesembilan, besikemelen (berkompetisi) yang saling memacu karir untuk keberhasilan, yang juga merupakan cermin ajaran Islam (Q.S.9: 105), dan bagi masyarakat Gayo berkompetisi ini juga lebih luas lagi dengan memahami keunggulan dan kelemahan diri sehnigga keahlian dan kemampuan diserahkan kepada ahlinya dengan membagi kedudukan adat yang dituangkan dalam kata pepatah Gayo, sibijak kin perawah, sikuet benemah (yang berilmu jadi juru bicara, yang kuat bekerja), sebagai semangat al-Qur'an bahwa orang Islam bekerja menurut ahlinya (Q.S.17: 84).

Dengan demikian jelaslah bahwa sistem nilai dalam masyarakat Gayo adalah bahagian dari ajaran Islam, maka sudah menjadi keyakinan masyarakat Gayo bahwa adat istidat adalah pagar atau pelindung ajaran Islam, setiap orang yang berpegang kepada adat sesungguhnya telah melakukan bagaian-bagian dari ajaran Islam. Sekiranya pengamalan ajaran Islam bersinergik dengan adat Gayo ini diharapkan masyarakat Gayo ini akan rajin, kreatif, dinamis, kompetitif sihingga hidupnya maju, modern dan sejahetera. Alasan itulah sebagai salah satu menjadi bekal daerah Aceh menjadi otonomi Syariat Islam.

\section{Penutup}

Sebagai penutup dari hasil kajian ini dapat disimpulkan bahwa sistem nilai pembangunan dalam masyarakat suku Gayo Indonesia masih dijabarkan dalam wujud sistem norma dari adat istiadat (edet) Gayo itu sendiri. Nilai-nilai adat di atas menjadi acuan bagi tindakan dalam berbagai sendi dan aspek kehidupan masyarakat Gayo, baik dalam

\footnotetext{
${ }^{69}$ Lebih luas dapat dibaca tentang budi luhur Muhammad SAW. sebelum menjadi Rasul, dalam Dr. Syafii Antoneo, Ensiklopedia Leadership \& Manajemen Muhammad SAW" The Super Leader Super Manager (Jakarta: Tazkia Publishing 2010), h. 78.
} 
kekerabatan, kepemimpinan, mata pencaharian, kesenian, upacara keagamaan, kenduri dan lain sebagainya. Semuanya untuk mewujudkan nilai-nilai pembangunan dalam masyarakat Gayo yang lebih maju, adil, makmur, sejahtera dan bermartabat. Nilai-nilai pembangunan itu semuanya akan dijadikan suatu ukuran baik dan buruk, atau apakah seseorang berperilaku tertib atau tidak dalam kehidupan sosial, agama dan budaya masyarakat Gayo.

Nilai pembangunan dalam masyarakat Gayo tersebut harus dipertahankan dan dijaga, karena prinsip-prinsip adat itu menyangkut pada harga diri (kemel). Oleh karena itu, dalam pandangan Islam nilai-nilai pembangunan dalam masyarakat Gayo itu sangat positif dan responsif, sebab antara nilai-nilai adat dan syariat tidak dapat dipisahkan dalam menunjang pelaksanaan pembangunan masyarakat Gayo dalam berbagai aspek kehidupan. Islam memandang bahwa nilai-nilai adat dan budaya itu sangat penting dalam memperkokoh keimanan (tauhid), dan meningkatkan kualitas ketakwaan serta mempererat ikatan silaturahmi, persatuan dan kesatuan bangsa dan negara.

\section{Pustaka Acuan}

A.R. Hakim, Aman Pinan, Daur Hidup Gayo, Arahan Adat, Kelahiran, Khitanan, Pendidikan dan Kematian. Takengon: Diterbitkan oleh Ikatan Cendikiawan Muslim Indonesia Orsat Aceh Tengah, 1998.

A.R. Hakim, Aman Pinan, Asal Linge Awal Serule. Takengon: Diterbitkan oleh Pemerintah Daerah Kabupaten Aceh Tengah, 2002.

C. Snouck Hurgronje, "Het Gajoland en Zijne Beworners", terj. Hatta Aman Asnah, Gayo, Masyarakat dan Kebudayaan Awal Abad ke-20. Jakarta, Balai Pustaka, 1996.

Dahlan, Abd. Aziz, Ensiklopedia Hukum Islam. Jakarta: PT. Ichtiar Baru Van Hoeve, 1999.

Daniel L. Pals, Seven Theories of Religion, E.B. Tylor-Clifford Geertz. New York: Oxford University Press, 1996.

Mahmud Ibrahim, et.al, Syariat dan Adat-Istiadat di Tanah Gayo. Takengon: Yayasan Maqamam Mahmuda, 2002.

Madjid, Nurcholis, Islam, Doktrin dan Peradaban, Sebuah Telaah Kritis Tentang Masalah Keimanan, Kemanusiaan, dan Kemodernan. Jakarta: Yayasan Wakaf Paramadina, 1992.

M.J. Melalatoa, Kebudayaan Gayo, Seri Etnografi Indonesia no.1. Jakarta: Penerbit Balai Pustaka, 1982.

M.J. Melalatoa, Budaya Malu: Sistem Budaya Gayo: Dalam Sistem Budaya Indonesia. Jakarta: UI Press, 1997.

Joan Ferranter, Sosiology A Global Perspective. United States of America: Northern Kentucky University, 1984.

John, R. Bowen, Religions In Practice, An Approach to the Anthropology of Religion. Washington University in St.Louis, tt. 
John, R. Bowen, Sumatran Politics And Poestics Gayo History, 1900-1989. New Haven and London: Yale University Press, 1991.

John, R. Bowen, Muslim Trough Discourse, Religion And Ritual in Gayo Society. Princeton, New Jersey, Princeton University Press, 1991.

Said Hawa, Al-Islam. Jakarta: Gema Insani, 2004.

Saliba, Jamil, Al-Mu'jam al-Falsafi, Juz II. Bairut: Penerbit, Daar al-Kitab, 1979.

Syafii Antoneo, Ensiklopedia Leadership \& Manajemen Muhammad SAW “ The Super Leader Super Manager. Jakarta: Tazkia Publishing 2010.

Syaltut, Muhammad, Al-Islamu Aqidatun Wa Syariatun, Cet. 3. Mesir: Daar al-Kalam, 1966.

Syukri, Sarakopat: Sistem Pemerintahan Tanah Gayo Dan Relevansinya Terhadap Pelaksanaan Otonomi Daerah. Jakarta: Hijri Pustaka Utama, 2006.

Tim Monografi Aceh Tengah, Monografi Daerah Aceh Tengah. Banda Aceh: Diterbitkan oleh Fakultas Ekonomi Universitas Syiah Kuala, 1981. 